\title{
Prospects for a Big Society? Special Issue of People Place and Policy Online
}

\section{Guest Editorial}

\author{
Peter Wells*
}

\section{The Emergence of an Idea}

In opposition and in government David Cameron has given prominence to the 'Big Society', second only to his case for public spending cuts and the reduction of the UK's budget deficit. He has set out the case for a Big Society in a series of lectures and speeches, initially and perhaps most thoroughly in his Hugo Young Lecture in 2009. In this lecture he called for a re-imagined role for the state which is not simply about a smaller state (some reheated version of ideological laissez-faire). Instead, we understand that the big society is not just going to spring to life on its own: we need strong and concerted government action to make it happen (David Cameron, 2009).

Themes which have run through successive speeches on the Big Society by David Cameron include:

- the redistribution of power from the central state to local communities and individuals

- greater transparency in the information individuals have so that they can make informed decisions, and

- with this, greater accountability.

These themes are carried forward into a case for greater social action, for the remaking and delivery of public services through charities, social enterprises and notably, the formation mutuals, and for the Big Society to reach beyond a narrow group of existing activists.

These themes are reflected strongly in the Coalition Agreement (HM Government, 2010) between the Conservative Party and the Liberal Democratic Party (see below). 
Social Action: Extracts from the Coalition Agreement

We will take action to support and encourage social responsibility, volunteering and philanthropy, and make it easier for people to come together in their communities and help one another.

We will support the creation and expansion of mutuals, co-operatives, charities and social enterprises.

We will give public sector workers a new right to form employee-owned co-operatives and bid to take these over the services they deliver.

We will train a new generation of community organisers and support the creation of neighbourhood groups across the UK, especially in the most deprived areas.

We will take a range of measures to encourage charitable giving and philanthropy.

We will introduce the National Citizen Service.

We will use funds from dormant bank accounts to establish a 'Big Society Bank', which will provide new finance for: neighbourhood groups, charities, social enterprises and other non-governmental bodies.

We will take a range of measures to encourage volunteering and involvement in social action.

\section{Big Government or Big Society?}

The 2010 election was fought on issues emanating from financial crisis and the recession, but most specifically on the rival parties' proposals for the reduction of the budget deficit (Smith, 2010). Rhetorically at least, Labour fought the campaign on a broadly Keynesian and traditional social democratic response to the crisis whilst the Conservatives advanced the case for a significantly smaller state and the creation of a space in which civil society could flourish. These same divides have largely characterised the post election political landscape, with the Coalition Government seeking to marry rapid reductions in public expenditure to the promotion of civic society and an emphasis on individual freedom and responsibility.

However, government's emphasis on the promotion of civil society is not new, and indeed the related ideas of social capital and communitarianism were important in shaping the politics of distinction and distance practiced in the early phases of the New Labour project, most significantly through the third way (Alcock, 2010; Kendall, 2003). However, whilst New Labour sought to marry a social democratic and redistributive agenda with social action, the emphasis for the Conservatives, and to some extent the Liberal Democrats, is for the state to withdraw from playing such a prominent role.

David Cameron's use of the Big Society is multi-faceted and is intended to address different audiences. At one level as the key contributor to the Big Society Philip Blond highlights, the Big Society provides a recasting of the very long standing Conservative concerns with the extent and role of the state in everyday life (Blond, 2010; Burke, 1790). At another level Big Society is intended to mark a break with 1980 s Thatcherism and the primary focus of government on ensuring the institutions for a free economy with little regard for the social consequences (Gamble, 1994). As such the Big Society is part of the 'detoxification' of the Conservative 'brand' (Bale, 2008). Steve Hilton, the Prime Minister's Director of Strategy, argues that what is being proposed is 'nothing less than to wean this country off its apparently unbreakable 
dependency upon the state, centralism, welfare, and rule from Whitehall' (Hilton 2010). As such, the rationale for the Big Society poses a considerable threat to the post-war welfare settlement.

For the moment, there is sufficient political support for the Big Society from the Conservatives and Liberal Democrats. As this parliament progresses there will inevitably be increasing pressures on specific policy agendas and on the Coalition Government agreement. If the benefits of the Big Society are not realised in the medium term, with little shared political advantage to be had, then the policy may be jettisoned for strategic or expedient reasons. The problem, as Cameron himself acknowledges, this is a policy which may take ten years or more to bear fruit.

A more fatalistic reading of the Big Society is that it advances both an analysis and a template for the UK in a post-welfare state, more contingent and changing world. It is therefore cognisant of the declining economic and political power of the UK in a changing and more fluid world. Whilst the relative decline of the UK is now at least a century old, the absolute material and resource consequences of decline will increasingly pose immediate challenges to this and future governments. In this postwelfare state world, Big Society does not call for the exit of the state, as some in the New Right may wish, but that responsibility for the provision of welfare rests much more with society and individuals. Shifting responsibility in this way appears to call for greater associative activity by people to respond to the challenges they face and a call for greater resilience in the face of change. Moreover Big Society cannot be divorced from political strategy, both within the Conservative Party, and beyond.

\section{About this Special Issue}

What has been striking about the promotion of the Big Society to date is that it makes only sporadic reference to evidence, in all its forms. At best it therefore appears a populist political agenda, but at worst as a cloak behind which to reduce the role of the state. This special issue of People, Place and Policy Online seeks to make a small contribution to filling this evidence gap. The article by Paul Lawless addresses this head on by drawing on the evaluation of New Deal for Communities (NDC). While NDC is not in any way a harbinger for Big Society it provides some of the most detailed evaluative evidence of any area based initiative ever undertaken in the United Kingdom. It serves to challenge the rationale that area based regeneration can be left to those resident in some of the most deprived neighbourhoods in the country.

The differing roles of the voluntary and community sector are picked up in separate articles by Cathy Pharoah and Richard Crisp et al., respectively. Cathy Pharoah's article explores the prospects for an increase in individual giving and philanthropy. The article presents evidence as to the mismatch between the causes donors choose and with statutory funding entering the sector. The rationale of the Big Society is that giving and philanthropy will in some way fill gaps in traditional areas of state provision, such as libraries or community centres, is not supported by evidence of current preferences. Moreover, the article raises the question as to whether a combination of incentives, civic responsibility and 'nudges' can be invoked to change these preferences and behaviour.

The article by Richard Crisp et al explores the role of the voluntary and community in delivering public services and reflects on growing use of prime contractor/subcontractor approaches for delivering welfare policies, both as part of the DWP Work Programme and the European Social Fund. This article finds some evidence to challenge established critiques, notably the positive experience of many third sector organisations working as sub-contractors to prime contractors. The paper also 
suggests however that some third sector organisations are more adept at being subcontractors in this regime, and raises questions around the risks of greater marketisation of the sector and loss of core values.

The issue of geography, and most critically the spatial social and economic divides in the United Kingdom, is given almost no mention in policies emanating from the Big Society. In an article by Peter Wells and colleagues a simple analysis of the geographical anatomy of the civil society in Yorkshire and Humber is undertaken. Whilst new localism calls for policies to be shaped by local residents it has the potential to result in considerable variation in service provision from place to place. Without attention to this variation and in particular the differing resources and capacities at the disposal of residents, it raises some stark implications with regards to the spatial justice and equity of the Big Society if its ambitions come to pass. More specifically it questions the rationale for civic action in areas where there is evidence neither of government failure or that civic action would achieve better outcomes.

The Big Society has sparked much academic activity and publication, to which this special issue makes one small contribution. In his article, Rob Macmillan provides a critical review of Bill Jordan's text Why the Third Way Failed? Macmillan uses this text as the basis to further our understanding of the voluntary and community sector. Most notably he introduces two key problems for the Big Society. Firstly, he outlines a concept of 'participation failure' (akin to market failure and government failure) to challenge both our understanding of participation and what high expectations policy makers often have of it. Secondly, and following Jordan's interests in 'club goods', Rob Macmillan outlines the concept of homophily in explaining the self organisation of civil society, and the potential risks of exclusion this brings. Common to both the work of Jordan and Macmillan is a critique of the third way as being overly concerned with contractual regulation between principals and utility maximisers, less with a broader narrative of moral or cultural regulation.

Finally, this issue makes a contribution to the emerging critiques of Big Society, and in particular draws on evidence to challenge some of the propositions the Coalition Government has put forward for the Big Society. There is of course far more evidence to draw on and far more tenets of Big Society to explore. Moreover, this issue does not subscribe to a rationalist understanding of evidence based policy making, rather one based on debate and discursive reasoning. In this vein, further contributions and challenges are welcomed by the editors of the journal.

* Correspondence Address: Peter Wells, CRESR, Sheffield Hallam University, Unit 10 Science Park, Howard Street, Sheffield, S1 1WB. Email: p.wells@shu.ac.uk.

\section{References}

Alcock, P. (2010) A strategic unity: defining the third sector in the UK. Voluntary Sector Review, 1, 1, 5-24.

Bale, T. (2008) A Bit Less Bunny-Hugging and a Bit More Bunny-Boiling? Qualifying Conservative Party Change under David Cameron. British Politics, 3, 270-299, (September 2008).

Blond, P. (2010) How the left and right have broken Britain and how we can fix it. London: Faber and Faber.

Burke, E. (1790; republished 1968) Reflections on the Revolution in France, and on the Proceedings in Certain Societies in London Relative to That Event. London: Penguin Classics. 
p. 54. Prospects for a Big Society? Special Issue of People Place and Policy Online: Guest Editorial

Cameron, D. (2010) The Big Society Hugo Young Lecture (10 November, 2009). Accessed from: www.conservatives.com/News/Speeches/2009/11/David Cameron_The Big_Society.aspx

Gamble, A. (1994) Free Economy and the Strong State. Palgrave Macmillan.

Hilton, S. (2010) Strategy Bulletin No 1 (16 th October). Accessed from: http://blogs.ft.com/westminster/2010/01/the-steve-hilton-strategy-bulletins/ (accessed 4 May 2011).

HM Government (2010) The Coalition Agreement (May 2010) accessed from: www.cabinetoffice.gov.uk/media/409088/pfg coalition.pdf

Kendall, J. (2003) The Voluntary Sector: Comparative Perspectives in the UK. London: Routledge.

Smith, M.J. (2010) From Big Government to Big Society: Changing the State-Society Balance. Parliamentary Affairs, 63, 4, 818-833. 